F. Reprod. Fert. (1972) 29, 157-162

\title{
THE RÔLE OF GLYCOGEN DURING THE DEVELOPMENT OF THE RAT TESTIS AND PROSTATE
}

\author{
K. P. GUNAGA, M. GHITRA RAO, A. R. SHETH AND SHANTA S. RAO \\ Division of Fundamental Research, \\ Institute for Research in Reproduction, \\ Jehangir Merwanji Street, Parel, Bombay 12
}

(Received 23rd November 1970, accepted 2nd August 1971)

\begin{abstract}
Summary. A study was carried out to assess the levels of glycogen and glycogen-degrading enzymes in rat testes from the fetal period to old age in order to elucidate the rôle of glycogen in gonadal maturation. Simultaneously, the capacity of the differentiating testes to secrete androgen was investigated using the maltase activity of the dorsolateral prostate as an index. High levels of glycogen and glycogen-degrading enzymes were observed to be present in the testes and dorsolateral prostate during fetal life. This suggests that glycogen serves as an important energy source for the testes during fetal development.
\end{abstract}

\section{INTRODUCTION}

The importance and significance of the glycogen-degrading enzymes in the male reproductive tract and its secretions have already been reported (Sheth \& Rao, 1962a, b; Gunaga, Sheth \& Rao, 1967; Sheth, Gunaga \& Rao, 1970). In order to ascertain whether glycogen serves as a source of carbohydrate during the development of the male gonad, the levels of glycogen and the glycogen-degrading enzymes, amylase and maltase, in the testis of prenatal, postnatal, mature and aged rats were studied. The capacity of the differentiating testis to secrete androgens was also investigated. Earlier work has established that the maltase activity of the dorsolateral prostate of the rat is androgendependent (Sheth, Gunaga \& Rao, 1967). This observation was used to develop a sensitive and specific assay for androgens using the maltase activity of the dorsolateral prostate of castrated rat as an index (Rao, Sheth \& Gunaga, 1969; Gunaga, Sheth \& Rao, 1970). The method of assessing androgen levels was employed for the work reported in this communication.

\section{MATERIALS AND METHODS}

Male, Wistar strain rats of ages varying from 15 prenatal to 630 postnatal days were used for these studies. The animals were divided into groups according to age, a total of 344 rats being used for the entire study.

The glycogen content of the testis and prostate tissues was determined by the method of Seifter, Dayton, Novic \& Muntwyler (1950). The results were 
expressed as $\mu \mathrm{g} / 100 \mathrm{mg}$ wet weight of tissue. Periodic acid-Schiff reaction with dimedone-blocking (Bulmer, 1959) was used for glycogen localization in the testis.

Maltase activity was assessed according to the method described by Gunaga et al. (1967). The results were expressed in terms of $\mathrm{mm}$ glucose/100 mg wet weight of tissue. Amylase activity was determined by the method of Bernfeld (1951). The enzyme activity was expressed in terms of mм maltose liberated/ $100 \mathrm{mg}$ wet weight of tissue.

\section{RESULTS}

The content of glycogen and of the glycogen-degrading enzymes in the testes of different age groups are given in Table 1. Prenatal rat testes showed the

TABLE 1

GLYGOGEN, AMYLASE AND MALTASE IN THE TESTES OF RATS OF DIFFERENT AGE GROUPS

\begin{tabular}{|c|c|c|c|c|}
\hline $\begin{array}{c}\text { Age } \\
\text { (days) }\end{array}$ & $\begin{array}{c}\text { No. of } \\
\text { rats }\end{array}$ & $\begin{array}{c}\text { Glycagen } \\
(\mu g / 100 \mathrm{mg} \\
\text { tissue })\end{array}$ & $\begin{array}{c}\text { Amylase ( } \mathrm{mM} \\
\text { maltose } / 100 \mathrm{mg} \\
\text { tissue) }\end{array}$ & $\begin{array}{c}\text { Maltase }(\mathrm{mM} \\
\text { glucose } / 100 \mathrm{mg} \\
\text { tissue })\end{array}$ \\
\hline $\begin{array}{c}\text { Prenatal } \\
15 \\
18 \\
20\end{array}$ & $\begin{array}{l}6 \\
6 \\
6\end{array}$ & $\begin{array}{l}455 \cdot 7 \pm 40 \cdot 8 \\
450 \cdot 8 \pm 53 \cdot 6 \\
388 \cdot 9 \pm 41 \cdot 3\end{array}$ & $\begin{array}{l}65 \cdot 1 \pm 6 \cdot 3 \\
56 \cdot 4 \pm 6 \cdot 2 \\
33 \cdot 4 \pm 5 \cdot 8\end{array}$ & $\begin{array}{c}52 \cdot 78 \pm 2 \cdot 39 \\
51 \cdot 7 \pm 2 \cdot 67 \\
35 \cdot 0 \pm 2 \cdot 0\end{array}$ \\
\hline $\begin{array}{c}\text { Postnatal } \\
1 \\
5 \\
10 \\
15 \\
20\end{array}$ & $\begin{array}{l}5 \\
5 \\
6 \\
8 \\
7\end{array}$ & $\begin{array}{c}314.5 \pm 29 \cdot 8 \\
46 \cdot 9 \pm 4 \cdot 9 \\
38 \cdot 0 \pm 3 \cdot 9 \\
29 \cdot 8 \pm 2 \cdot 8 \\
21 \cdot 0 \pm 2 \cdot 0\end{array}$ & $\begin{array}{l}17.8 \pm 1.8 \\
16.8 \pm 1.8 \\
13.9 \pm 1.6 \\
12.6 \pm 1.7 \\
10.6 \pm 1.2\end{array}$ & $\begin{array}{l}40 \cdot 6 \pm 2 \cdot 11 \\
35 \cdot 6 \pm 1 \cdot 89 \\
33 \cdot 9 \pm 2 \cdot 22 \\
33 \cdot 3 \pm 2 \cdot 34 \\
25 \cdot 0 \pm 1.67\end{array}$ \\
\hline $\begin{array}{c}\text { Immature } \\
25 \\
30 \\
40 \\
50\end{array}$ & $\begin{array}{l}5 \\
5 \\
5 \\
5\end{array}$ & $\begin{array}{c}9 \cdot 3 \pm 1 \cdot 0 \\
7 \cdot 0 \pm 0 \cdot 60 \\
1 \cdot 6 \pm 0 \cdot 12 \\
11 \cdot 8 \pm 1 \cdot 3\end{array}$ & $\begin{array}{c}6 \cdot 8 \pm 0.52 \\
13 \cdot 2 \pm 1 \cdot 3 \\
27 \cdot 3 \pm 1 \cdot 8 \\
13 \cdot 4 \pm 1.0\end{array}$ & $\begin{array}{l}21 \cdot 1 \pm 1 \cdot 11 \\
31 \cdot 1 \pm 1 \cdot 45 \\
42 \cdot 8 \pm 1 \cdot 78 \\
15 \cdot 6 \pm 1 \cdot 11\end{array}$ \\
\hline $\begin{array}{r}\text { Mature } \\
90 \\
180 \\
270\end{array}$ & $\begin{array}{l}6 \\
5 \\
4\end{array}$ & $\begin{array}{l}25 \cdot 6 \pm 1 \cdot 9 \\
22 \cdot 5 \pm 1 \cdot 98 \\
22 \cdot 0 \pm 2 \cdot 2\end{array}$ & $\begin{array}{r}5 \cdot 8 \pm 0 \cdot 4 \\
12 \cdot 1 \pm 0 \cdot 9 \\
14 \cdot 1 \pm 1 \cdot 3\end{array}$ & $\begin{array}{r}8 \cdot 9 \pm 1 \cdot 00 \\
16 \cdot 7 \pm 1 \cdot 00 \\
23 \cdot 9 \pm 1 \cdot 22\end{array}$ \\
\hline $\begin{array}{r}\text { Aged } \\
360 \\
480 \\
630\end{array}$ & $\begin{array}{l}5 \\
4 \\
4\end{array}$ & $\begin{array}{l}20 \cdot 0 \pm 2 \cdot 0 \\
17 \cdot 0 \pm 2 \cdot 1 \\
19 \cdot 8 \pm 2 \cdot 2\end{array}$ & $\begin{array}{r}10 \cdot 3 \pm 1 \cdot 0 \\
10 \cdot 2 \pm 1 \cdot 1 \\
9 \cdot 1 \pm 1 \cdot 3\end{array}$ & $\begin{array}{l}17 \cdot 2 \pm 1 \cdot 11 \\
20 \cdot 6 \pm 1 \cdot 28 \\
16 \cdot 7 \pm 1 \cdot 17\end{array}$ \\
\hline
\end{tabular}

Values expressed as Mean \pm S.E.

presence of very high levels of glycogen and also of amylase and maltase. Glycogen, which was present in considerable amounts $(314 \mu \mathrm{g} / 100 \mathrm{mg}$ tissue) in the testes of a 1-day-old rat, decreased progressively during the immediate postnatal period until puberty. Thereafter, a moderate increase was observed in the glycogen content (11 to $26 \mu \mathrm{g}$ ) of the testes. These values, however, remained constant between the period of 90 to 630 days after birth.

The abundant amounts of glycogen found in testes of fetal (15- to 20-day) 
and 1-day-old rats were confirmed by the results of histochemical localization. In these testes, glycogen was observed to be mainly localized in the tunica albuginea, gonocytes and supporting cells. Glycogen granules were also seen in the Leydig cells. Fewer glycogen granules were seen in the testis of the 5-day-old rat than in those of the fetal and newborn rat. These granules were mainly localized in the germinal cells (gonocytes and type A cells). A slight positive reaction was also observed in the supporting cells. Glycogen could not be detected in the testis from Day 10 until puberty. From Day 60 onwards, a very faint stain for glycogen was seen in this organ.

The amylase content was high in the prenatal testes. A gradual decline in the levels of this enzyme was observed after birth until Day 25, after which an

TABLE 2

LEVELS OF GLYGOGEN, AMYLASE, AND MALTASE IN THE DORSOLATERAL PROSTATE OF RATS OF DIFFERENT AGE GROUPS

\begin{tabular}{|c|c|c|c|c|}
\hline $\begin{array}{c}\text { Age } \\
(\text { days })\end{array}$ & $\begin{array}{c}\text { No. of } \\
\text { rats }\end{array}$ & $\begin{array}{c}\text { Glycogen } \\
(\mu g / 100 \mathrm{mg} \\
\text { tissue })\end{array}$ & $\begin{array}{c}\text { Amylase }\langle\mathrm{mM} \\
\text { maltose } 100 \mathrm{mg} \\
\text { tissue })\end{array}$ & $\begin{array}{c}\text { Maltase (mM } \\
\text { glucose } / 100 \mathrm{mg} \\
\text { tissue) }\end{array}$ \\
\hline $\begin{array}{c}\text { Prenatal } \\
15 \\
18 \\
20\end{array}$ & $\begin{array}{l}6 \\
5 \\
5\end{array}$ & $\begin{array}{l}2202 \pm 192 \cdot 3 \\
830 \cdot 9 \pm 89 \cdot 8 \\
634 \cdot 9 \pm 65 \cdot 6\end{array}$ & $\begin{array}{l}48 \cdot 6 \pm 5 \cdot 2 \\
47 \cdot 5 \pm 4 \cdot 8 \\
51 \cdot 8 \pm 5 \cdot 3\end{array}$ & $\begin{array}{l}32 \cdot 6 \pm 2 \cdot 0 \\
30 \cdot 3 \pm 2 \cdot 22 \\
32 \cdot 2 \pm 1 \cdot 89\end{array}$ \\
\hline $\begin{array}{c}\text { Postnatal } \\
1 \\
5 \\
10 \\
15 \\
20\end{array}$ & $\begin{array}{l}5 \\
5 \\
5 \\
8 \\
7\end{array}$ & $\begin{array}{c}1464 \cdot 5 \pm 159 \cdot 0 \\
248 \cdot 8 \pm 26 \cdot 3 \\
95 \cdot 3 \pm 10 \cdot 2 \\
113 \cdot 2 \pm 10 \cdot 3 \\
124 \cdot 6 \pm 11 \cdot 6\end{array}$ & $\begin{array}{r}38 \cdot 9 \pm 4 \cdot 0 \\
25 \cdot 73 \pm 2 \cdot 8 \\
26 \cdot 2 \pm 2 \cdot 0 \\
25 \cdot 4 \pm 3 \cdot 2 \\
22 \cdot 0 \pm 2 \cdot 4\end{array}$ & $\begin{array}{l}30 \cdot 0 \pm 1 \cdot 78 \\
27 \cdot 2 \pm 1 \cdot 33 \\
25 \cdot 0 \pm 1 \cdot 39 \\
23 \cdot 3 \pm 1 \cdot 11 \\
21 \cdot 7 \pm 1 \cdot 22\end{array}$ \\
\hline $\begin{array}{c}\text { Immature } \\
25 \\
40 \\
50\end{array}$ & $\begin{array}{l}5 \\
5 \\
5\end{array}$ & $\begin{array}{c}154 \cdot 1 \pm 13 \cdot 9 \\
48 \cdot 1 \pm 4 \cdot 1 \\
71 \cdot 0 \pm 6 \cdot 9\end{array}$ & $\begin{array}{l}22 \cdot 9 \pm 2 \cdot 3 \\
50 \cdot 6 \pm 4 \cdot 4 \\
29 \cdot 2 \pm 3 \cdot 2\end{array}$ & $\begin{array}{l}24.4 \pm 1.11 \\
27.8 \pm 1.67 \\
29.4 \pm 1.50\end{array}$ \\
\hline $\begin{array}{r}\text { Adult } \\
90 \\
180 \\
270\end{array}$ & $\begin{array}{l}6 \\
5 \\
4\end{array}$ & $\begin{array}{c}119 \cdot \overline{4} \pm 10 \cdot 2 \\
137 \cdot 1 \pm 11 \cdot 9\end{array}$ & $\begin{array}{r}30 \cdot 7 \pm 3 \cdot 1 \\
23 \cdot 97 \pm 2 \cdot 2 \\
23 \cdot 1 \pm 2 \cdot 2\end{array}$ & $\begin{array}{l}34.4 \pm 1.78 \\
18.9 \pm 1 \cdot 0 \\
11 \cdot 1 \pm 0.67\end{array}$ \\
\hline $\begin{array}{r}\text { Aged } \\
360 \\
480 \\
630\end{array}$ & $\begin{array}{l}5 \\
4 \\
4\end{array}$ & $\begin{array}{c}227 \cdot 0 \pm 21 \cdot 3 \\
149 \cdot 0 \pm 13 \cdot 9 \\
-\end{array}$ & $\begin{array}{l}27 \cdot 3 \pm 2 \cdot 8 \\
40 \cdot 0 \pm 3 \cdot 9 \\
10 \cdot 8 \pm 2 \cdot 2\end{array}$ & $\begin{array}{l}16.9 \pm 0.87 \\
18.3 \pm 0.78 \\
16.1 \pm 0.67\end{array}$ \\
\hline
\end{tabular}

Values expressed as Mean \pm S.E.

increase occurred in the enzyme activity. The maximum activity was observed on Day 40 after birth. After this time, the enzyme activity decreased and remained constant (Table 1).

Testicular maltase activity was also relatively high in the testes of prenatal rats and up to 15 days after birth but then started to decline. The levels rose again until they were maximum in the testes of 40-day-old rats. A further rapid decline to a fairly constant level then followed.

The dorsolateral prostate of fetal and 1-day-old rats exhibited a high maltase activity $(30.0$ to $32.6 \mathrm{~mm} / 100 \mathrm{mg}$ wet $\mathrm{wt})$. The enzyme level then decreased gradually to a low level (21.7) in the prostate of 20-day-old rats but, thereafter, 
the enzyme activity increased. The maltase activity of the dorsolateral prostate of adult, 90-day-old rats (34.4) was similar to the levels observed in fetal and new born rats. Between 180 to 270 days, maltase activity fell to a minimum (Table 2).

Amylase did not follow the same pattern as maltase (Table 2). The high levels of glycogen observed in the dorsolateral prostate of prenatal rats, declined rapidly in the immediate postnatal period and were lowest in 40-day-old animals. An increase in the glycogen level occurred after Day 40 (Table 2).

\section{DISGUSSION}

Leiderman \& Mancini (1969) recently reported on the glycogen content of rat testis. They observed a relationship between the glycogen content and gonadal maturation. Glucose has also been shown to be an essential substrate for maintaining tissue integrity, ATP production and protein synthesis in the rat testes (Mancini, Penhos, Izquierdo \& Heinrich, 1960; Firlit \& Davis, 1966; Means \& Hall, 1968a, b). The availability of glucose in the testes is, in turn, naturally dependent on the degradation of glycogen. The high levels of glycogen and its degrading enzymes observed in the fetal testes suggest that glycogen may be an important source of energy for the growing gonads.

It was of interest to note that the levels of amylase and maltase, were elevated when the glycogen level was lowest in the testis of 40-day-old rats. The apparently low glycogen values observed would seem most probably to be due to a higher rate of glucose utilization. The key sites of glucose metabolism in the rat testes are known to be present in the more advanced germinal cells (spermatocytes and spermatids) (Tepperman \& Tepperman, 1950; Paul, Paul, Kopko, Bender \& Everett, 1953; Davis, Morris \& Hollinger, 1964; Hollinger \& Davis, 1968). Davis \& Firlit (1965) have shown by autoradiographic studies that spermatocytes and spermatids are the principal sites for glucose stimulation of protein synthesis in rat testis. Spermiogenesis takes place in the early puberal period. The results reported in this communication suggest that glycogen might be degraded at this stage, releasing glucose which is used for the metabolism of the actively growing testis tissue.

The maltase activity of the dorsolateral prostate in the rat has been shown to be androgen dependent (Sheth et al., 1967). The present finding that the prostates of prenatal rats exhibit high maltase activity (Table 1) supports the observation of Noumura, Weisz \& Lloyd (1966) that fetal testes are capable of producing androgen.

Steinberger \& Ficher (1969) demonstrated a biphasic character of differentiation in the testes to convert progesterone to testosterone. This capacity was shown to be maximal at birth and to diminish almost to zero at the age of 20 days. Thereafter, there was a gradual increase in the conversion, with maximal levels occurring in the 90-day-old rat. Resko, Feder \& Goy (1968) observed high levels of testosterone in the plasma and testes of 1-day-old rats. The level of the steroid decreased gradually until only traces could be detected in 15- to 40-day-old rats. A subsequent gradual increase after Day 40 occurred, with peak levels at Day 90 . The values for maltase activity in the different age groups 
are in agreement with the values for testosterone reported by the above workers. Their results confirm our earlier findings that the maltase level of the dorsolateral prostate in rats could be taken as an index of the androgenic function of the testis.

The fluctuations in the maltase activity of the dorsolateral prostate noted in the present study may reflect changes in the responsiveness of the prostate with age. Mainwaring (1968) has shown that the administration of testosterone to 9-month-old animals did not evoke any pronounced change in the biochemistry of the prostate, though it did produce significant changes in the biochemical parameters of the prostates of 30-month-old rats.

It was reported by Singhal, Wang \& Ling (1968) that the administration of testosterone increases the glycogen content of the rat prostate. The results of the present study indicate that glycogen metabolism forms an important pathway for energy production in growing rats. The sharp decline in glycogen content observed in the immediate postnatal period occurred in the testis as well as in the prostate. The lowest amount of glycogen observed in the testis and the prostate of 40-day-old rats was concomitant with increasing levels of the glycogen-degrading enzymes studied. The results reported so far suggest that the histochemical and biochemical parameters used in the present study are indicative of the significant changes occurring in the spermatogenic and androgenic functions of the rat testis.

\section{ACKNOWLEDGMENTS}

We are grateful to Shri Ashok Kundapur for his help in standardizing the histochemical method. We acknowledge the help of the World Health Organization in donating the chemicals used in this study.

\section{REFERENCES}

Bernfeld, P. (1951) Enzymes of starch degradation and synthesis. Adv. Enzymol. 12, 379.

Bulmer, D. (1959) Dimedone as an aldehyde blocking reagent to facilitate the histochemical demonstration of glycogen. Stain Technol. 34, 95.

DAvis, J. R. \& FirLIT, G. F. (1965) Effect of glucose on uptake of L-lysine- $\mathrm{H}^{3}$ in cells of the seminiferous epithelium. Am. F. Physiol. 209, 425.

DAVIS, J. R., Morris, R. N. \& Hollinger, M. A. (1964) Incorporation of L-lysine-U- ${ }^{14} \mathrm{C}$ into proteins of cryptorchid testis slices. Am. 7. Physiol. 207, 50.

Firlit, C. F. \& Davis, J. R. (1966) Radio-autographic incorporation of L-lysine- ${ }^{3} \mathrm{H}$ into protein of cells of the germinal epithelium in cryptorchidism. F. Reprod. Fert. 11, 125.

Gunaga, K. P., Sheth, A. R. \& Rao, Shanta S. (1967) Maltase activity in the accessory reproductive organs of rats and mice. Indian 7. exp. Biol. 5, 141.

Gunaga, K. P., Sheth, A. R. \& Rao, S. (1970) Steroid induced changes in the maltase activity of the dorsolateral prostate of castrated rats. Steroids, 15, 613.

Hollinger, M. A. \& Davis, J. R. (1968) Aerobic metabolism of uniformly labelled $\left[{ }^{14} \mathrm{C}\right]$ glucose in tissue slices of rat testes. F. Reprod. Fert. 17, 343.

LeIDERMAN, B. \& MANCINI, R. E. (1969) Glycogen content in the rat testis from postnatal to adult ages. Endocrinology, 85, 607 .

Mancini, R. E., Penhos, J., Izquierdo, I. A. \& Heinrich, J. D. (1960) Effects of acute hypoglycemia on rat testis. Proc. Soc. exp. Biol. Med. 104, 699.

Mainwaring, W. I. P. (1968) The effect of testosterone on the age-associated changes in the ventral prostate gland of the mouse. Testosterone and aging of the prostate. Gerontologia, 14, 133.

Means, A. R. \& Hall, P. F. (1968a) Protein biosynthesis in the testis: I. Comparison between stimulation by FSH and glucose. Endocrinology, 82, 597. 
Means, A. R. \& Hall, P. F. (1968b) Protein biosynthesis in the testis: II. Role of adenosine triphosphate (ATP) in stimulation by glucose. Endocrinology, 83, 86.

Noumura, T., Weisz, J. \& Lloyd, Ch. W. (1966) In vitro conversion of $7-{ }^{3} \mathrm{H}$-progesterone to androgens by the rat testis during the second half of fetal life. Endocrinology, 78, 245.

Paul, H. E., Paul, M. F., Kopko, F., Bender, R. G. \& Everett, G. (1953) Carbohydrate metabolism studies on the testis of rats fed certain nitrofurans. Endocrinology, 53, 585.

Rao, S. S., Sheth, A. R. \& Gunaga, K. P. (1969) Assay of androgenicity of steroids using maltase activity of dorsolateral prostate of the rat as an index. Indian F. exp. Biol. 7, 20.

Resko, J. A., FEDER, H. H. \& Goy, R. W. (1968) Androgen concentrations in plasma and testis of developing rats. F. Endocr. 40, 485.

Seifter, S. S., Dayton, S., Novic, B. \& Muntwyler, E. (1950) The estimation of glycogen with the anthrone reagent. Arch. Biochem. 25, 191.

Sheth, A. R., Gunaga, K. P. \& Rao, S. S. (1967) Effect of gonadectomy and sex hormones on maltase activity of accessory reproductive organs of rats. Indian $\mathcal{7}$. exp. Biol. 5, 144.

Sheth, A. R., Gunaga, K. P. \& Rao, S. S. (1970) Occurrence of amylo-1,6-glucosidase in human seminal plasma: its properties and significance in sperm metabolism. F. Reprod. Fert. 22, 77.

Sheth, A. R. \& Rao, S. S. (1962a) Maltase activity in human semen. Experientia, 18, 370.

Sheth, A. R. \& Rao, S. S. (1962b) Purification and properties of human seminal maltase. F. Reprod. Fert. 4, 267.

Singhal, R. L., Wang, D. \& Ling, G. M. (1968) Actinomycin: inhibition of testosterone-stimulated glycogen synthesis in the rat prostate and seminal vesicles. Life Sci. Part II, 7, 485.

Steingerger, E. \& Ficher, M. (1969) Differentiation of steroid biosynthetic pathways in developing testes. Biol. Reprod. Suppl. 1, 119.

Tepperman, H. M. \& Tepperman, J. (1950) Glucose utilization in vitro by normal, adult, immature and cryptorchid rat testis. Endocrinology, 47, 459. 